Review paper

\title{
Orchidaceae in the Pieniny Mountains (Western Carpathians)
}

\author{
Ludwik Frey
}

Department of Systematics and Phytogeography, W. Szafer Institute of Botany, Polish Academy of Sciences, Lubicz 46, 31-512 Kraków, Poland, e-mail: 1.frey@botany.pl

\begin{abstract}
Orchids constitute an important component of the Pieniny Mts. flora. The presence of 35 orchid species has been noted so far in this region. A considerable number of these species are endangered for various reasons. Eight species have been deemed extinct in the area. On the other hand, the orchid flora of the Pieniny Mts. includes species that widen their local ranges and can, thus, be considered expansive as well as new species, recently entered in the list of orchids occurring in the said mountain range (Epipactis microphylla and Epipactis muelleri). It is necessary and important to conduct an inventory of Pieniny orchid resources (the major aim of this study) that would be repeated at certain intervals, in order to know the number of stations and of individuals per population of each species, which would enable taking relevant actions needed to prevent the disappearance of these plants from the Pieniny Mts.
\end{abstract}

Key words: Orchids, Carpathians, Pieniny Mts., flora, protection, threats, "red list", "red book"

\section{Introduction}

The occurrence of approximately 60 species of Orchidaceae has been recorded in Poland to date, and all these are under strict legal protection (Mirek et al. 2002; Regulation... 2012). Stations of some of them are only of historical value because they have not been confirmed in recent years. A number of these species have been entered into national "Red Lists" (Zarzycki 1986; Zarzycki \& Szelagg 1992; Zarzycki \& Szelag 2006) as well as "Red Books" (Zarzycki \& Kaźmierczakowa 1993; Kaźmierczakowa \& Zarzycki 2001).

Orchids constitute an important component of the Pieniny flora, both from botanical and aesthetic viewpoints. The presence of 35 orchid species has been noted so far in this region (Zarzycki 1981; Naumowicz 2008; Wróbel 2008) (Table 1). They include eight species that have been deemed extinct in the area (Zarzycki 1981). A considerable number of orchids are endangered for various reasons. According to the national "Red Book" (Kaźmierczakowa \& Zarzycki 2001a), there are eight such species, and according to the national "Red List" (Zarzycki \& Szelagg 2006) - 17, while the "Red Data Book of the Carpathians" reports nine species (Mirek \& Piękoś-Mirkowa 2008).
The species most commonly found in this region include: Dactylorhiza fuchii, D. majalis, Epipactis atrorubens, E. helleborine, Gymnadenia conopsea, Listera ovata, Neottia nidus-avis, Orchis mascula, O. morio, Platanthera bifolia, and Traunsteinera globosa (Zarzycki 1981; Zarzycki \& Wróbel 2012). Rarely occurring species include: Cephalanthera damasonium, C. longifolia, Coeloglossum viride, Corallorhiza trifida, Dactylorhiza maculata, D. sambucina, and Epipactis palustris (Zarzycki 1981; Bodziarczyk \& Vončina 2001; Kaźmierczakowa \& Perzanowska 2001; Kolankowska et al. 2012; Zarzycki \& Wróbel 2012). The following species have been found in very few sites: Cypripedium calceolus, Epipogium aphyllum, Goodyera repens, Malaxis monophyllos, Ophrys insectifera, Orchis ustulata, and Platanthera chlorantha (Zarzycki 1981; Kaźmierczakowa \& Perzanowska 2001; Vončina 2010). New species, recently entered in the list of orchids occurring in the said mountain range are: Epipactis microphylla (Wróbel 2008) and Epipactis muelleri (Naumowicz 2008). The orchid flora of the Pieniny Mountains also includes species that widen their local ranges and can, thus, be considered expansive.

Systematic botanical research in the Pieniny Mountains began already in the nineteenth century, and it 
was continued in the first half of the twentieth century. However, a full description of the Pieniny floral resources, including orchids, was completed towards the end of 1970s (Zarzycki 1981; Zarzycki \& Wróbel 2012). Since then, fairly scarce studies on the flora of the Pieniny Mountains have been published, which also include information concerning orchids (see list of references). In the Slovakian part of the Pieniny Mountains, floristic research was conducted in 1990s by Benčat'ová (2001).

The aim of this paper is to compile reports of changes that have occurred since the 1980s in the composition of orchid flora in the Polish part of the Pieniny Mountains. Data has been presented in Table as well as notes concerning the species that do not currently occur in the Pieniny Mountains and species that are very rare or new. Factors that cause threats to many species, particularly rare ones and causes of expansion of several orchid species in the area have also been briefly described. This study has used the species nomenclature according to Mirek et al. (2002).

\section{Species not currently found in the Pieniny Mountains}

Cephalanthera rubra (L.) Rich. - A species dispersed in Poland, but rare in the mountains. Nearly half of its stations currently remain unconfirmed (Zając \& Zając 2001; Bernacki 2008a). In danger of extinction in Poland (Hereźniak \& Bernacki 2001), currently known only from one station in the Carpathians - critically endangered (Bernacki 2008a) - see Table 1. Sightings of this species were reported in Szczawnica in the Pieniny Mountains (Zieleniewski 1852 as cited by Zarzycki 1981), but these were later unconfirmed. The species was recorded in the Slovakian Pieniny Mountains (Zarzycki 1981).

Dactylorhiza incarnata (L.) Soó - Non-threatened on a national scale. Subsp. incarnata growing in the Carpathians, reported only in the vicinity of Przemyśl (Zając \& Zając 2001; Bernacki 2008b). Other few Carpathian stations do not exist or have long not been confirmed - critically endangered (Bernacki 2008b). Generally reported from the Pieniny Mountains (Berdau 1890 as cited by Zarzycki 1981), and the western Pieniny Mountains - Księża Młaka mire (Gustawicz 1894 as cited by Zarzycki 1981). In the Slovakian part of the Pieniny Mountains - Červený Kláštor (Filarszky 1898 as cited by Zarzycki 1981). Probably no herbarium specimens.

Gymnadenia odoratissima (L.) Rich. - Species known in Poland only from the Tatra Mountains and from an unconfirmed station in the Sudety Mountains (Zając \& Zając 2001), non-threatened on a national scale. Reported from the Pieniny Mountains, most likely by mistake (Filarszky 1888 as cited by Zarzycki 1981).

Listera cordata (L.) R. Br - A relatively widespread species in the mountains of Poland (the Carpathians and Sudety) and in the northern part of the country, particularly along the Baltic shore (Zając \& Zając 2001). Classified as vulnerable to extinction (Table 1). Generally reported from the Pieniny Mountains (Knapp 1872 as cited by Zarzycki 1981), from Szczawnica (Zieleniewski 1852 as cited by Zarzycki 1981) and Slovakia - Kláštorná hora (Gustawicz 1881, 1894 preserved herbarium specimens, as cited by Zarzycki 1981). Later not found for a long time.

Orchis coriophora L. - Deemed extinct in Poland until 2001 - threat level category EX (Zając \& Zając 2001; Bernacki \& Adamowski 2001). After the discovery of new stations (Głowacki et al. 2004; Krawczyk 2008), the current category is $\mathrm{E}$ (Table 1); however, its occurrence in the Polish Carpathians has not been confirmed (Bernacki 2008d). All data from the Pieniny Mountains date back to the nineteenth century. It was recorded from these mountains both generally (Berdau 1860, 1890, as cited by Zarzycki 1981) and, specifically, from Zamkowa Góra (central Pieniny Mountains) (Herbich 1834 as cited by Zarzycki 1982) and Wysokie Skałki (Little Pieniny Mountains - the highest altitude they occur in Poland) regions (Gustawicz 1894 as cited by Zarzycki 1981).

Orchis militaris L. - Reported in Poland from numerous sites in the north-western and eastern parts of the country. Its occurrence has been recently confirmed in approximately 50 sites out of nearly 200 formerly known (Zając \& Zając 2001; Bernacki \& Bartoszek 2008). Vulnerable to extinction in Poland, critically endangered in the Carpathians (Bernacki \& Bartoszek 2008) - see Table 1 . It probably used to occur quite frequently before the end of the nineteenth century, e.g. on Czerniawa Glade (Gustawicz 1881, as cited by Zarzycki 1981; herbarium specimens). Later deemed extinct in the Polish part of the Pieniny Mountains (Zarzycki 1981), but recently recorded in Slovakia (Zarzycki \& Wróbel 2012).

Orchis pallens L. - A small number of stations can be found in southern Poland where the north-eastern border of its range runs (Zając \& Zając 2001; Bernacki et al. 2008). In Poland and the Polish Carpathians, this species is vulnerable to extinction (Zając 2001; Bernacki et al.2008) - see Table 1. Reported in the Pieniny Mountains in Upszar forest (Gustawicz 1881, 1894 as cited by Zarzycki 1981; herbarium specimens), as well as Szczawnica (Zieleniewski 1852 as cited by Zarzycki 1981). These are nowadays historical stations (Bernacki et al. 2008; Zarzycki \& Wróbel 2012).

Pseudorchis albida (L.) Á. Löve \& D. Löve - It occurs very rarely in the Sudety Mountains, slightly more frequently in the Carpathians, not found for a 
Table 1. Orchidaceae species recorded in the Pieniny Mts. and their threat category

\begin{tabular}{|c|c|c|c|c|c|c|c|}
\hline \multirow{2}{*}{$\begin{array}{c}\text { Pieniny Mts. } \\
1981\end{array}$} & \multirow{2}{*}{ Species } & \multicolumn{3}{|c|}{ Polish Red List } & \multicolumn{2}{|c|}{$\begin{array}{c}\text { Polish Red } \\
\text { Book }\end{array}$} & \multirow{2}{*}{$\begin{array}{l}\text { CRB } \\
2008\end{array}$} \\
\hline & & 1986 & 1992 & 2006 & 1993 & 2001 & \\
\hline - & Cephalanthera damasonium (Mill.) Druce & $\mathrm{V}$ & $\mathrm{R}$ & $\mathrm{V}$ & - & - & - \\
\hline - & Cephalanthera longifolia (L.) Fritsch & V & $\mathrm{V}$ & $\mathrm{V}$ & - & - & - \\
\hline+ & Cephalanthera rubra (L.) Rich. & $\mathrm{V}$ & $\mathrm{E}$ & $\mathrm{E}$ & - & $\mathrm{EN}$ & - \\
\hline - & Coeloglossum viride (L.) Hartm. & - & $\mathrm{V}$ & $\mathrm{V}$ & - & - & - \\
\hline - & Corallorhiza trifida Châtel. & - & $\mathrm{V}$ & $\mathrm{V}$ & - & - & - \\
\hline - & Cypripedium calceolus $\mathrm{L}$. & $\mathrm{V}$ & $\mathrm{V}$ & $\mathrm{V}$ & - & VU & $\mathrm{EN}$ \\
\hline - & Dactylorhiza fuchsii (Druce) Soó & $\mathrm{V}$ & $\mathrm{V}$ & $\mathrm{V}$ & - & - & - \\
\hline+ & Dactylorhiza incarnata (L.) Soó & - & - & - & - & $\mathrm{EN}$ & - \\
\hline - & Dactylorhiza maculata (L.) Soó & V & $\mathrm{V}$ & $\mathrm{V}$ & - & - & - \\
\hline$\circ$ & Dactylorhiza majalis (Rchb.) P. F. Hunt. \& Summerh. & - & - & - & - & - & - \\
\hline - & Dactylorhiza sambucina (L.) Soó & $\mathrm{V}$ & $\mathrm{V}$ & $\mathrm{V}$ & - & VU & $\mathrm{EN}$ \\
\hline$\circ$ & Epipactis atrorubens (Hoffm.) Besser & - & - & - & - & - & - \\
\hline$\circ$ & Epipactis helleborine (L.) Crantz & - & - & - & - & - & - \\
\hline - & Epipactis microphylla (Ehrh.) Sw. & $\mathrm{E}$ & $\mathrm{E}$ & $\mathrm{V}$ & $\mathrm{E}$ & EN & $\mathrm{EN}$ \\
\hline - & Epipactis muelleri Godfery & - & - & - & - & - & $\mathrm{EN}$ \\
\hline - & Epipactis palustris (L.) Crantz & $\mathrm{V}$ & $\mathrm{V}$ & $\mathrm{V}$ & - & - & - \\
\hline - & Epipogium aphyllum $\mathrm{Sw}$. & $\mathrm{R}$ & $\mathrm{V}$ & $\mathrm{E}$ & - & $\mathrm{CR}$ & $\mathrm{EN}$ \\
\hline - & Goodyera repens (L.) R. Br. & - & - & {$[\mathrm{E}]$} & - & - & - \\
\hline$\circ$ & Gymnadenia conopsea (L.) R. Br & - & - & - & - & - & - \\
\hline+ & Gymnadenia odoratissima (L.) Rich. & - & - & - & - & - & - \\
\hline+ & Listera cordata (L.) R. Br. & - & - & {$[\mathrm{V}]$} & - & - & - \\
\hline$\circ$ & Listera ovata (L.) R. Br. & - & - & - & - & - & - \\
\hline - & Malaxis monophyllos (L.) Sw. & $\mathrm{V}$ & $\mathrm{R}$ & $\mathrm{V}$ & $\mathrm{V}$ & LR & $\mathrm{EN}$ \\
\hline$\circ$ & Neottia nidus-avis (L.) Rich. & - & - & - & - & - & - \\
\hline - & Ophrys insectifera L. & $\mathrm{R}$ & $\mathrm{R}$ & $\mathrm{R}$ & $\mathrm{R}$ & VU & $\mathrm{EN}$ \\
\hline+ & Orchis coriophora $\mathrm{L}$. & $\mathrm{E}$ & $\mathrm{E}$ & $\mathrm{E}$ & - & EX & - \\
\hline - & Orchis mascula (L.) L. & - & $\mathrm{V}$ & $\mathrm{V}$ & - & - & - \\
\hline+ & Orchis militaris L. & V & $\mathrm{V}$ & $\mathrm{V}$ & - & - & - \\
\hline घ & Orchis morio L. & - & $\mathrm{V}$ & $\mathrm{V}$ & - & $\mathrm{EN}$ & $\mathrm{EN}$ \\
\hline+ & Orchis pallens L. & $\mathrm{V}$ & $\mathrm{V}$ & $\mathrm{V}$ & $\mathrm{V}$ & VU & - \\
\hline - & Orchis ustulata L. & $\mathrm{V}$ & $\mathrm{E}$ & $\mathrm{R}$ & - & EN & CR \\
\hline$\circ$ & Platanthera bifolia (L.) Rich. & - & - & - & - & - & - \\
\hline$\circ$ & Platanthera chlorantha (Custer) Rchb. & - & - & - & - & - & - \\
\hline+ & Pseudorchis albida (L.) Á. Löve \& D. Löve & - & - & - & - & - & - \\
\hline$\circ$ & Traunsteinera globosa (L.) Rchb. & - & - & - & - & - & - \\
\hline
\end{tabular}

Explanations: threat degrees in the Pieniny Mts., + extinct, - endangered, o not threatened; regions - Pieniny Mts. (Zarzycki 1981); Poland - Polish Red List of Plants (Zarzycki 1986; Zarzycki \& Szelag 1992; Zarzycki \& Szelag 2006); Poland - Polish Red Book of Plants (Zarzycki \& Kaźmierczakowa 1993; Kaźmierczakowa \& Zarzycki 2001); Carpathians - CRB (The Red Data Book of the Polish Carpathians) (Mirek \& Piękoś-Mirkowa, 2008); threat categories in Poland and in Carpathians, EX - extinct, CR - critically endangered, E, EN - endangered/declining - critically endangered, $[\mathrm{E}]-$ declining - critically endangered, high risk of extinction in isolated localities beyond the main area of occurrence, $\mathrm{V}, \mathrm{VU}$ - vulnerable, [V] - vulnerable, endangered in isolated localities beyond the main area of occurrence, $\mathrm{R}$ - rare/potentially endangered

long time in many of its stations (Zając \& Zając 2001; Piękoś-Mirkowa \& Mirek 2006). Not entered in the Polish "Red List" or "Red Book". Locally (e.g. in the Sudety Mountains), it is critically endangered (Fabiszewski \& Kwiatkowski 2002). Noted in the Pieniny Mountains "in forests near Szczawnica" (Berdau 1890 as cited by Zarzycki 1981; this information is more likely to refer to the Sacz region) and in the Biała Woda valley (Kostuch 1966 as cited by Zarzycki 1981). Later not found.

\section{Very rare species in the Pieniny Mountains}

Cypripedium calceolus L. - Recorded in Poland from approximately 250 , mostly lowland, stations ranging from the Lubuskie lake district through Masuria to the Suwalskie lake district, and occurs in the south in the Sudety Mountains and the Carpathians (Zając \& Zając 2001). In the Polish part of the Carpathians, it had slightly more than 30 stations; it has lately been confirmed only in approximately one-third of these stations 
(Mirek \& Bernacki 2008). For the threat level categories on a national scale and in the Carpathians (Table 1). Protected by the Bern Convention and Habitat Directive (Bąba \& Kucharczyk 2001; Zarzycki \& Szelag 2006; Mirek \& Bernacki 2008). Recorded at ten stations in the Pieniny Mountains. For a certain time, it was reported at the western and central parts of the Pieniny Mountains; in the Little Pieniny Mountains only on the Slovakian side. The first account of its occurrence on the Polish side in this part of the Pieniny Mountains dates back to 1990 (Witkula mountain, north-eastern slope - station currently requires confirmation). A heliophilous species, declining due to the regeneration of tree stands (Babczyńska-Sendek et al. 1980; Zarzycki 1981; Mirek \& Bernacki 2008; Zarzycki \& Wróbel 2012).

Epipogium aphyllum Sw. - It occurs in Poland mostly in the south (Carpathians and Sudety Mountains), rarely in lowland areas (Zając \& Zając 2001). It has been recorded in the Carpathians at 20 stations. It has not been recently confirmed in the majority of these sites. Its current distribution is focused in the Tatra Mountains (Piękoś-Mirkowa et al. 2008). For the threat level categories on a national scale and in the Carpathians (Hereźniak \& Piękoś-Mirkowa 2001; Zarzycki \& Szelag 2006; Piękoś-Mirkowa et al. 2008) - see Table 1. Two historical stations in the central Pieniny Mountains Pieniński Potok River (Knapp 1872 as cited by Zarzycki 1981) and Sokolica Mountain (Gustawicz 1881, 1894; as cited by Zarzycki 1981; herbarium specimens) later unconfirmed. A present-day station in the Harczy Grunt valley was observed from 1994 to 2005. The number of individuals gradually declined when, finally, only one blooming individual was still left in 2005. This species is endangered mainly due to its scarceness and the fact that populations are small in number. When growing near tourist trails, it is under threat of trampling (Piątek \& Vončina 1995; Bodziarczyk \& Vončina 2001; PiękośMirkowa et al. 2008).

Goodyera repens (L.) R. Br. - In Poland, found mostly in Western Pomerania and the north-eastern part of the country. Recorded in the Sudety and Carpathians Mountains (Zając \& Zając 2001; Piękoś-Mirkowa \& Mirek 2006). For the threat level category on a national scale - see Table 1 (Zarzycki \& Szelag 2006). Reported only from the Little Pieniny Mountains up until the 1980s, where it was collected in 1973 in the Skalski Potok River gorge, and from Slovakia (Aksamitka Mt.) (Zarzycki 1981). A new station was found in 2007 near Czorsztyn, located beyond the reach of human economic activities, which is promising for its survival (Vončina 2010). In general, the major threat to this species in Poland is the commercial use of forests (Piękoś-Mirkowa \& Mirek 2006).

Malaxis monophyllos (L.) Sw. - Approximately 300 stations of this species have been recorded in Poland, both in lowland areas and mountains. The number of its stations solely in the Carpathians was nearly 60 in former times. Nowadays, almost half of them are considered extinct or no longer found since as early as the turn of the nineteenth and twentieth centuries. The species currently occurs in the western Tatra Mountains (Zając \& Zając 2001; Bernacki 2008c). For the threat level categories on a national scale and in the Polish Carpathians (Bernacki 2001, 2008c; Zarzycki \& Szelag 2006) - see Table 1. Noted in the Pieniny Mountains near Szczawnica and Krościenko in eight stations in the nineteenth century. Not found again in the following years (Zarzycki 1981). It was not until 2000 that several stations were recorded in the western and central Pieniny Mountains and one in the Little Pieniny Mountains. Populations are usually small in size (a few or, less commonly, about a dozen individuals) (Kaźmierczakowa \& Perzanowska 2000; Bodziarczyk \& Vončina 2001; Bernacki \& Błońska 2006). The most severe threat is posed by draining moist forests and shrubland areas, regulating the flow and lining the riversides of mountain streams, as well as the deliberate structural transformation of deciduous and mixed forests into coniferous forests (Bernacki 2008c).

Ophrys insectifera L. - Approximately 30 stations are known in the south of Poland (in the Carpathians and Małopolska Upland), situated beyond the continuous range of this species. In the Polish Carpathians, it can be found only in the Tatra and Pieniny Mountains (Zajacc \& Zając 2001; Mirek \& Stawowczyk 2008). For the threat level categories on a national scale and in the Polish Carpathians (Kaźmierczakowa \& Zarzycki 2001b; Zarzycki \& Szelag 2006; Mirek \& Stawowczyk 2008) - see Table 1. Its occurrence has been recorded in all parts of the Pieniny Mountains. Since the beginning of the twentieth century, it has only been reported in Czorsztyn and on Holica mountain. Quite rare in 1970s, although it occasionally occurred at many sites in large numbers (Zarzycki 1981). Towards the end of 1980s, it was recorded in just two locations (Jagiełło 1992). Only several stations have been found in the western Pieniny Mountains since 2000 (Kaźmierczakowa \& Perzanowska 2001; Bernacki \& Błońska 2006; Kolanowska et al. 2012). Endangered due to small numbers of individuals in populations, scarcity of occurrence, and the succession of trees and shrubs (Mirek \& Stawowczyk 2008).

Orchis ustulata L. - Currently a fairly rare species in Poland (approximately 130 stations, now predominantly historical ones), and very rare in the Carpathians (Zając \& Zając 2001; Mirek et al. 2008). Two subspecies can be distinguished: subsp. ustulata (blooming in May and June) and subsp. aestivalis (blooming in July and August). For the threat level categories on a national scale and in the Polish Carpathians (Table 1). Protected 
by the Washington Convention (Bernacki \& Krukowski 2001; Zarzycki \& Szelag 2006; Mirek et al. 2008). It occurred very rarely in the Pieniny Mountains in 1970s, whereas in the nineteenth century, it was possibly more common in the area, as confirmed by data from that period (Zarzycki 1981; Mirek et al. 2008). Two stations on the Polish side of the Pieniny Mountains were known for a short time, namely Kórnikówka Glade (central Pieniny Mountains) and Wysoki Wierch Mt. (Little Pieniny Mountains), the latter discovered in 2006, both of which currently require confirmation. It is likely that the species, which is associated with warm meadows, disappeared from the Polish part of the massif, although it was recorded on the Slovakian side in the Haligovce region (Frey \& Frey 2006; Mirek et al. 2008; Zarzycki $\&$ Wróbel 2012). Threatened due to very small populations, scarcity of its occurrence and afforestation of meadows (Mirek et al. 2008).

Platanthera chlorantha (Custer) Rchb. - Dispersed in Poland and fairly common in the southern, eastern, and north-eastern parts of the country, as well as in the Sudety Mountains and Carpathians (Zając \& Zając 2001). The species is non-threatened on a national scale. Considered rare in the Pieniny Mountains. Reported in central and western parts, including Slovakia (Zarzycki 1981; Jagiełło 1992). Found in 2009 in the Little Pieniny Mountains (Szafranówka Mt.) (L. Frey, unpubl.). It is possible that there are more stations, as the species is sometimes confused with P. bifolia. Directly threatened as a result of people picking them and, indirectly, by the commercial use of deciduous forests (Piękoś-Mirkowa \& Mirek 2006).

\section{Orchid species new to the Pieniny Mountains}

Newly occurring orchids in the Pieniny Mountains are represented by two (or three?) species of the Epipactis genus.

Epipactis microphylla (Ehrh.) Sw. - A Mediterranean species, its range reaches as far north as Poland's southern regions. Eight stations have been known to date, located in the southern part of the country (Zając \& Zając 2001; Wróbel 2008). For the threat level category on a national scale and in the Carpathians (Baryła 2001; Zarzycki \& Szelagg 2006; Wróbel 2008) - see Table 1. In 1998, it was found in the central Pieniny Mountains (southern slope of Pieninki, in a Carici-Fagetum cephalanteretosum community) (Wróbel 1999). Observations continued from 1998 to 2007 showed a variable number of individuals producing fairly abundant blooms (no seedlings found). The small population does not seem to be directly threatened; however, a random event may negatively affect its occurrence. Therefore, this orchid has been included in the list of species of special interest in the Pieniny National Park (Wróbel 2008).
Epipactis muelleri Godfery - A Western and Central European species, reported in Poland only from three sites. Due to its resemblance to Epipactis helleborine s. lato, this species could have been previously misidentified, which suggests that further stations are yet to be found. Not entered in the national "Red List" or "Red Book"; included in the "Red List" of species of the Lower Silesia region (Kącki 2003; Naumowicz 2008) - see Table 1. It has been, so far, recorded in the Pieniny Mountains at just one site in the central Pieniny Mountains (Wyrobek Glade) in 2008. The population, which comprises merely four blooming individuals, is greatly threatened because of its location near a tourist trail. Constant monitoring, the preservation of seeds in a seed bank and entering the species in the national "Red List" are recommended steps (Naumowicz 2008).

Epipactis purpurata $\mathrm{Sm}$. - Threat level category $\mathrm{R}$ (Zarzycki \& Szelag 2006). The station from the Pieniny Mountains reported by Jagiełło (1992) is doubtful. It was not confirmed in the following years; it has not been referred to in literature concerning plant distribution in Poland (e.g. Zając \& Zając 2001; Piękoś-Mirkowa \& Mirek 2006).

\section{Species showing expansive tendencies in the Pieniny Mountains}

On the basis of research by Bernacki and Błońska (2006), it was found that 11 orchid species occurred in an anthropogenic zone (environs of the Krośnica Niedzica road, western Pieniny Mountains) at stations formed as a result of construction works. These were mainly species with the largest number of stations in the Pieniny Mountains (Dactylorhiza fuchii, D. majalis, Epipactis atrorubens, E. helleborine, Gymnadenia conopsea, Listera ovata and Platanthera bifolia), as well as those classified as rare (Cephalanthera damasonium and Epipactis palustris) and very rare species (Malaxis monophyllos and Ophrys insectifera).

The following species, which occurred more frequently in the anthropogenic zone than the undisturbed zone, were deemed the most expansive: Epipactis palustris, E. helleborine, Listera ovata, Gymnadenia conopsea, Dactylorhiza fuchii, and Epipactis atrorubens. The latter three produced the largest numbers of sprouts in the anthropogenic zone. The abundant occurrence of orchids in human-transformed habitats probably results from the creation of specific habitat conditions, such as high humidity and insolation levels, with the concomitant suppression of competition from herbaceous plants, shrubs and trees.

\section{Final remarks}

The abundance of Orchidaceae species still endures in the Pieniny Mountains. It is evident from the above- 
presented compilation that both commonly found species, forming numerous populations, and rare species, with no more than single stations and the populations that produce small numbers of flowering sprouts, occur in this region. Regrettably, many species that had still been recorded in the nineteenth and early twentieth century disappeared and other, formerly abundant species, survived only at single stations.

The Pieniny orchid flora, together with other vascular plant species of this mountain range, undergoes constant quantitative and qualitative transformations. This is caused both by natural factors, which seem inevitable, and by human activity that can be modelled relative to needs (Zarzycki \& Wróbel 2012). For instance, as a result of changes in the management, particularly substantial changes occurred in meadow flora, of which orchids are an important component. These changes pertain to the withdrawal from exten- sive meadow management, intensification of meadow use, the abandonment of meadows or the introduction of grazing. For these reasons, orchids disappear from their stations, as they rapidly show negative response to habitat changes. On the other hand, it is interesting to observe particular species colonising habitats where they have not occurred before.

Despite the fact that these plants are under legal protection, most of them having been entered in "Red Lists" and "Red Books", orchids still require special conservation efforts. It is, therefore, necessary and important to conduct an inventory of orchid resources (the major aim of this study) that would be repeated at certain intervals in order to know the number of stations and of individuals per population of each species. This, in turn, would make it possible to take relevant actions needed to prevent the disappearance of these plants from the Pieniny Mountains.

\section{References}

BabczyŃSKa-Sendek B., Cabala S. \& Kimsa T. 1980. Nowe stanowisko obuwika pospolitego Cypripedium calceolus w Małych Pieninach. Chrońmy Przyr. Ojcz. 46(1): 73-77.

BaryŁa J. 2001. Epipactis microphylla - Kruszczyk drobnolistny. In: R. KAźmierCZAKowa \& K. ZARZYCKI (eds.). Polska Czerwona Księga Roślin. Paprotniki i rośliny kwiatowe, pp. 533-534. Instytut Botaniki im. W. Szafera PAN i Instytut Ochrony Przyrody PAN, Kraków.

BąBA W. \& KucharczyK L. 2001. Cypripedium calceolus - Obuwik pospolity. In: R. KaźmierCZAKowa \& K. ZARZYCKi (eds.). Polska Czerwona Księga Roślin. Paprotniki i rośliny kwiatowe, pp. 529-530. Instytut Botaniki im. W. Szafera PAN i Instytut Ochrony Przyrody PAN, Kraków.

BenČAŤová B. 2001. Cievnaté rastliny Pienin. 177 pp. Arbora Publishers.

BERNACKI L. 2001. Malaxis monophyllos - Wyblin jednolistny. In: R. KaźmierczaKowa \& K. Zarzycki (eds.). Polska Czerwona Księga Roślin. Paprotniki i rośliny kwiatowe, pp. 576-578. Instytut Botaniki im. W. Szafera PAN i Instytut Ochrony Przyrody PAN, Kraków.

BERNACKI L. 2008a. Buławik czerwony - Cephalanthera rubra. In: Z. Mirek \& H. Piękoś-Mirkowa (eds.). Czerwona Księga Karpat Polskich. Rośliny naczyniowe, pp. 439-440. Instytut Botaniki im. W. Szafera PAN i Instytut Ochrony Przyrody PAN, Kraków.

BERNACKi L. 2008b. Kukułka (Storczyk, Stoplamek) krwista typowa - Dactylorhiza incarnata subsp. incarnata. In: Z. Mirek \& H. Piękoś-Mirkowa (eds.). Czerwona Księga Karpat Polskich. Rośliny naczyniowe, pp. 450452. Instytut Botaniki im. W. Szafera PAN i Instytut Ochrony Przyrody PAN, Kraków.
BERNACKI L. 2008c. Wyblin jednolistny - Malaxis monophyllos. In: Z. Mirek \& H. PięKoś-Mirkowa (eds.). Czerwona Księga Karpat Polskich. Rośliny naczyniowe, pp. 471-473. Instytut Botaniki im. W. Szafera PAN i Instytut Ochrony Przyrody PAN, Kraków.

BERNACKI L. 2008d. Storczyk cuchnący - Orchis coriophora. In: Z. Mirek \& H. PięKoś-Mirkowa (eds.). Czerwona Księga Karpat Polskich. Rośliny naczyniowe, pp. 486487. Instytut Botaniki im. W. Szafera PAN i Instytut Ochrony Przyrody PAN, Kraków.

Bernacki L. \& AdAmowsKi W. 2001. Orchis coriophoraStorczyk cuchnący. In: R. KAźmierCZAKowa \& K. ZARzycKi (eds.). Polska Czerwona Księga Roślin. Paprotniki i rośliny kwiatowe, pp. 558-560. Instytut Botaniki im. W. Szafera PAN i Instytut Ochrony Przyrody PAN, Kraków.

Bernacki L. \& Bartoszek W. 2008. Storczyk kukawka Orchis militaris. In: Z. MireK \& H. PIĘKOŚ-MirkowA (eds.). Czerwona Księga Karpat Polskich. Rośliny naczyniowe, pp. 477-479. Instytut Botaniki im. W. Szafera PAN i Instytut Ochrony Przyrody PAN, Kraków.

BernACKi L. \& BŁońsKa A. 2006. Występowanie storczykowatych (Orchidaceae) w otoczeniu południowego odcinka drogi Krośnica-Niedzica w Pienińskim Parku Narodowym. Pieniny-Przyroda i Człowiek 9: 65-70.

Bernacki L. \& Krukowski M. 2001. Orchis ustulata - Storczyk drobnokwiatowy. In: R. KAźmIERCZAKowa \& K. ZARZYCKi (eds.). Polska Czerwona Księga Roślin. Paprotniki i rośliny kwiatowe, pp. 560-562. Instytut Botaniki im. W. Szafera PAN i Instytut Ochrony Przyrody PAN, Kraków.

Bernacki L., Pacyna A. \& Nejfeld P. 2008. Storczyk blady - Orchis pallens. In: Z. MireK \& H. PięKOŚ-MirkowA 
(eds.). Czerwona Księga Karpat Polskich. Rośliny naczyniowe, pp. 483-485. Instytut Botaniki im. W. Szafera PAN i Instytut Ochrony Przyrody PAN, Kraków.

Bodziarczyk J. \& VončIna G. 2001. Nowe i rzadkie gatunki roślin naczyniowych Pienińskiego Parku Narodowego. Fragm. Flor. Geobot. Polonica 20: 11-20.

FABisZewski J. \& Kwiatkowski P. 2002. Threatened Vascular Plants of the Sudeten Mountains. Acta Soc. Bot. Pol. 71(4): 339-350.

Frey L. \& Frey W. 2006. Stanowisko Orchis ustulata (Orchidaceae) w Małych Pieninach. Fragm. Flor. Geobot. Polonica 13(2): 423-425.

Glowacki Z., Grużewska T., Grużewski M. \& Raczuk J. 2004. Nowe stanowisko Orchis coriophora (Orchidaceae) w dolinie Narwi pod Wizną (południowowschodnia Polska). Fragm. Flor. Geobot. Polonica 11(2): 287-292.

HereźniaK J. \& Bernacki L. 2001. Cephalantera rubraBuławik czerwony. In: R. KAżMierczaKowa \& K. ZARZYCKI (eds.). Polska Czerwona Księga Roślin. Paprotniki i rośliny kwiatowe, pp. 536-537. Instytut Botaniki im. W. Szafera PAN i Instytut Ochrony Przyrody PAN, Kraków.

HereźniaK J. \& PięKoś-Mirkowa H. 2001. Epipogium aphyllum - Storzan bezlistny. In: R. KAźMIerCZAKowa \& K. ZARZYCKi (eds.). Polska Czerwona Księga Roślin. Paprotniki i rośliny kwiatowe, pp. 538-540. Instytut Botaniki im. W. Szafera PAN i Instytut Ochrony Przyrody PAN, Kraków.

JAGIEŁŁo M. 1992. Storczyki łąk i polan Pienińskiego Parku Narodowego. Pieniny - Przyroda i Człowiek 2: 43-49.

KĄCKI Z. (ed.). 2003. Zagrożone gatunki flory naczyniowej Dolnego Śląska. 245 pp. Instytut Biologii Roślin, Uniwersytet Wrocławski, Polskie Towarzystwo Przyjaciół Przyrody „Pro Natura”, Wrocław.

Kaźmierczakowa R. \& Perzanowska J. 2000. Wyblin jednolistny Malaxis monophyllos w Pieninach. Chrońmy Przyr. Ojcz. 56(3): 84-86.

Kaźmierczakowa R. \& Perzanowska J. 2001. Notatki florystyczne z Pienin. Fragm. Flor. Geobot. Polonica 8: 3-9.

Kaźmierczakowa R. \& Zarzycki K. (eds.). 2001a. Polska Czerwona Księga Roślin. Paprotniki i rośliny kwiatowe. 664 pp. Instytut Botaniki im. W. Szafera PAN i Instytut Ochrony Przyrody PAN, Kraków.

Kaźmierczakowa R. \& Zarzycki K. 2001b. Ophrys insectifera - Dwulistnik muszy. In: R. KAźMIERCZAKOwA \& K. ZARZYCKi (eds.). Polska Czerwona Księga Roślin. Paprotniki i rośliny kwiatowe, pp. 572-574. Instytut Botaniki im. W. Szafera PAN i Instytut Ochrony Przyrody PAN, Kraków.

Kolankowska M., Naumowicz J., Naczk A. \& Święczkowska E. 2012. Dwulistnik muszy Ophrys insectifera (Orchidaceae) w Pienińskim Parku Narodowym - nowe stanowiska. Chrońmy Przyr. Ojcz. 68(2): 143-145.

KRAWCZYK R. 2008. Nowe stanowisko storczyka cuchnącego Orchis coriophora (Orchidaceae) w Kotlinie Sandomierskiej. Chrońmy Przyr. Ojcz. 64(3): 57-62.
Mirek Z. \& Bernacki L. 2008. Obuwik pospolity - Cypripedium calceolus. In: Z. MireK \& H. PięKoś-Mirkowa (eds.). Czerwona Księga Karpat Polskich. Rośliny naczyniowe, pp. 447-449. Instytut Botaniki im. W. Szafera PAN i Instytut Ochrony Przyrody PAN, Kraków.

Mirek Z. \& PięKoś-Mirkowa H. (eds.) 2008. Czerwona Księga Karpat Polskich. Rośliny naczyniowe. 615 pp. Instytut Botaniki im. W. Szafera PAN i Instytut Ochrony Przyrody PAN, Kraków.

Mirek Z. \& StAwOWCZyK K. 2008. Dwulistnik muszy - Ophrys insectifera. In: Z. Mirek \& H. PięKoś-Mirkowa (eds.). Czerwona Księga Karpat Polskich. Rośliny naczyniowe, pp. 474-476. Instytut Botaniki im. W. Szafera PAN i Instytut Ochrony Przyrody PAN, Kraków.

Mirek Z., Pięroś-Mirkowa H. \& Beczala T. 2008. Storczyk drobnokwiatowy - Orchis ustulata. In: Z. MiReK \& H. PięKoś-Mirkowa (eds.). Czerwona Księga Karpat Polskich. Rośliny naczyniowe, pp. 491-493. Instytut Botaniki im. W. Szafera PAN i Instytut Ochrony Przyrody PAN, Kraków.

Mirek Z., Piękoś-Mirkowa H., ZająC A. \& Zając M. 2002. Flowering plants and pteridophytes of Poland. A checklist. In: Z. MireK (ed.). Biodiversity of Poland, 1, 442 pp. W. Szafer Institute of Botany, Polish Academy of Sciences, Kraków.

Naumowicz J. 2008. Kruszczyk Muellera - Epipactis muelleri. In: Z. Mirek \& H. Piękoś-Mirkowa (eds.). Czerwona Księga Karpat Polskich. Rośliny naczyniowe, pp. 466-467. Instytut Botaniki im. W. Szafera PAN i Instytut Ochrony Przyrody PAN, Kraków.

PiĄTeK G. \& VonČInA G. 1995. Stanowisko storzana bezlistnego Epipogium aphyllum w Pieninach. Chrońmy Przyr. Ojcz.. 51(4):68-70.

PięKoś-Mirkowa H. \& Mirek Z. 2006. Rośliny chronione. Flora Polski. 417 pp. MULTICO Oficyna Wydawnicza, Warszawa.

PięKoś-Mirkowa H., Koczur A. \& Bodziarczyk J. 2008. Storzan bezlistny - Epipogium aphyllum. In: Z. MireK \& H. Pięroś-Mirkowa (eds.). Czerwona Księga Karpat Polskich. Rośliny naczyniowe, pp. 468-470. Instytut Botaniki im. W. Szafera PAN i Instytut Ochrony Przyrody PAN, Kraków.

Regulation of the Minister of Environment of 05 JanuARY 2012 on wild species of plants under protection. Journal of Laws No 0 (2012), 81.

VončInA G. 2010. Tajęża jednostronna Goodyera repens (L.) R. Br. - nowy przedstawiciel storczykowatych Orchidaceae w Pienińskim Parku Narodowym. Pieniny - Przyroda i Człowiek 11: 33-38.

Wróbel I. 1999. Nowe stanowisko Epipactis microphylla (Orchidaceae) w Polsce. Fragm. Flor. Geobot. Polonica $6: 282-284$.

WróBel I. 2008. Kruszczyk drobnolistny - Epipactis microphylla. In: Z. Mirek \& H. PięKoś-Mirkowa (eds.). Czerwona Księga Karpat Polskich. Rośliny naczyniowe, pp. 463-465. Instytut Botaniki im. W. Szafera PAN i Instytut Ochrony Przyrody PAN, Kraków.

ZAJĄC M. 2001. Orchis pallens - Storczyk blady. In: R. Kaźmierczakowa \& K. Zarzycki (eds.). Polska 
Czerwona Księga Roślin. Paprotniki i rośliny kwiatowe, pp. 566-568. Instytut Botaniki im. W. Szafera PAN i Instytut Ochrony Przyrody PAN, Kraków.

Zając A. \& Zając M. (eds.). 2001. Distribution Atlas of Vascular Plants in Poland. xii+714 pp. Edited by Laboratory of Computer Chorology, Institute of Botany, Jagiellonian University, Cracow.

ZARZYCKI K. 1981. Rośliny naczyniowe Pienin. 257 pp. PWN, Warszawa-Kraków.

ZARZYCKI K. 1986. List of threatened Vascular Plants in Poland. In: K. ZARZYCKI \& W. Wojewoda (eds.). List of threatened plants in Poland, pp. 11-27. PWN, Warszawa.

ZARZYCKI K. \& KAŹMIERCZAKOWA R. (eds.). 1993. Polska Czerwona Księga Roślin. Paprotniki i rośliny kwiatowe.
310 pp. Instytut Botaniki im. W. Szafera PAN i Instytut Ochrony Przyrody PAN, Kraków.

ZARZYCKI K. \& SZELĄG Z. 2006. Red list of the vascular plants in Poland. In: Z. MireK, K. Zarzycki, W. WojewodA \& Z. Szeląg (eds.). Red list of plants and fungi in Poland, pp. 9-20. W. Szafer Institute of Botany, Polish Academy of Sciences, Kraków.

ZARZYCKI K. \& SZELĄG Z. 1992. Red list of threatened vascular plants in Poland. In: K. ZARZYCKI, W. WoJEWODA \& Z. HeInRICH (eds.). List of threatened Plants in Poland, pp. 87-98. W. Szafer Institute of Botany, Polish Academy of Sciences, Kraków.

ZARZYCKI K. \& WróBel I. 2012. Przemiany pienińskiej flory roślin naczyniowych w XX wieku. Pieniny - Przyroda i Człowiek 12: 43-56. 